\title{
China and international law: Two tales of an encounter
}

\author{
Jean d'Aspremont ${ }^{1}\left(\mathbb{D}\right.$ and Binxin Zhang $^{2}$ \\ ${ }^{1}$ Sciences Po Law School and University of Manchester, 27 Rue Saint-Guillaume, 75337 Paris Email: jean.daspremont@ \\ manchester.ac.uk and ${ }^{2} \mathrm{PhD}$ Researcher, Centre for International Studies, Science Po, 27 Rue Saint-Guillaume, 75337 \\ Paris Email: zbinxin@gmail.com
}

\begin{abstract}
This article examines how the encounter between China and international law is narrated in the Englishspeaking and Chinese literature and sheds light on the politics thereof. It particularly shows that the English-speaking and Chinese-speaking literature diverge as to the order of meaning in which the encounter between China and international law is registered. It demonstrates that the divergences between these bodies of literature are everything but innocent.
\end{abstract}

Keywords: China; critical history; history of international law; narrativization

\section{Introduction}

Most disciplines are articulated around some carefully designed disciplinary histories. Such disciplinary histories are indispensable for disciplines to ground themselves as much as their object and methods of inquiry into a past that is held as being real rather than imaginative. ${ }^{1}$ Once grounded into a past deemed real, disciplines as much as their object and their methods of inquiry come to be experienced as a universal necessity. Interestingly, the constitution of a past deemed real into which disciplines can be grounded is often produced through the narrativization of some key and carefully selected events as part of an order of meaning which confirms the reality of the disciplines concerned. ${ }^{2}$ The constitution of a past deemed real though the narrativization of some key and carefully selected events is a very common discursive device to confer upon disciplines, their object, and their methods of inquiry, a universal necessity.

International law is not different. In fact, international law is constantly presented as being grounded in some key past events which are themselves narrativized as part of an order of meaning which confirms the universal necessity of international law. ${ }^{3}$ This article focuses on one of such key events, namely the so-called encounter between China and international law in the nineteenth century. In fact, just as the so-called Peace of Westphalia was made as a founding moment of international law, ${ }^{4}$ the encounter between China and international law came to be presented as

\footnotetext{
${ }^{1}$ The invocation of 'nature' as the ultimate truth-claiming criteria is a common feature of technical modern discourses. See, generally, B. Latour, Science in Action: How to Follow Scientists and Engineers Through Society (1987).

${ }^{2}$ H. White, The Content of the Form. Narrative Discourse and Historical Representation (1987), at 5. See also R. Barthes, 'le discours de l'histoire', (1967) 6 (4) Social Science Information 63.

${ }^{3}$ See, generally, J. d'Aspremont, 'Critical Histories of International Law and the Repression of Disciplinary Imagination', (2019) 7 London Review of International Law, at 89-115.

${ }^{4} \mathrm{On}$ the arbitrariness of the choice for 1648 see M. Craven, 'Introduction: International Law and Its Histories', in M. Craven, M. Fitzmaurice and M. Vogiatzi (eds.), Time, History and International Law (2007), at 8. See also B. Fassbender, 'Peace of Westphalia (1648)', Max Planck Encyclopedia of Public International Law (2011), para. 7, at 18-19. Andreas Osiander has located the choice of Westphalia as a key event in the history of international law in the work of 
a very central event in the history of international law and made part of an order of meaning reinforcing the universal necessity of international law, of its object, and of its methods of inquiry.

What is particularly striking regarding the elevation of the encounter of China and international law into a key event of the history of international law and its belonging to an order of meaning that confirms the universal necessity of international law is that this set of facts is registered as such in both English-speaking and Chinese-speaking scholarship. Said differently, English-speaking and Chinese-speaking scholars embrace what is called here a shared eventalization. As is shown here, this shared eventalization is not the only resemblance between Englishspeaking and Chinese-speaking historical narratives. In fact, the facts constitutive of the encounter between China and international law are not only recognized as a central event of the disciplinary history of international law in both English-speaking and Chinese-speaking scholarship but are narrated in the same way in both bodies of literature, thereby denoting a shared narrativization in the historical narratives around which they are organized. Indeed, in both English-speaking and Chinese-speaking literature, most accounts of the encounter between China and international law are articulated around a narrative of imposition whereby international law is said to have been imposed by Western powers on China.

The fact that the encounter between China and international law is subject to a shared eventalization as well as a shared narrativization in both English-speaking and Chinese-speaking literature, is an important premise for the argument developed in this article. It is argued here that these shared eventalization and narrativization of the facts constitutive of the encounter between China and international law actually hide that the English-speaking and Chinese-speaking histories of international law respectively offer two very distinct tales of this encounter. In other words, behind the elevation of the encounter between China and international law into a central event of the history of international law (shared eventalization) and its subjection to the same narrative of imposition (shared narrativization), the encounter between China and international law is registered as belonging to divergent orders of meaning in the English-speaking and Chinese-speaking literature. Although this article primarily aims to shed light on the different orders of meaning at work behind the shared eventalization and narrativization witnessed in the English-speaking and Chinese-speaking histories of international law, it will show that the divergences between the orders of meaning pursued by each of these bodies of literature are everything but innocent.

A few terminological observations are in order. First, for the sake of this article, eventalization refers to the particularization of a set of facts into a key historical marker and their recognition as an unordinary occurrence with a view to segmenting and organizing the historical discourse. ${ }^{5}$ As far as international law is concerned, the common elevation of the publication of Grotius' De Jure Belli ac Pacis, the Peace of Westphalia, the encounter between China and international law, the Alabama arbitration, the Hague Peace conferences, etc. into key events of the history of international law constitute a specific - and certainly not innocent - type of eventalization. Second, by narrativization, this article refers to the organization of the past around a type of intrigue ${ }^{6}$

\footnotetext{
Nys: See A. Osiander, 'Sovereignty, 'International Relations, and the Westphalian Myth', (2001) 55 (2) International Organization 251. For José-Manuel Barreto the origin of this periodization goes back as early as 1845 with Henry Wheaton: See J. Barreto, 'Cerberus: Rethinking Grotius and the Westphalian System', in M. Koskenniemi, W. Rech and M. Jimenez Fonseca (eds.), International Law and Empire (2017), at 159-60. For the claim that the myth of Westphalia was created by Leo Gross in the middle of the twentieth century see L. Eslava, M. Fakhri and V. Nesiah, Bandung, Global History and International Law. Critical Pasts and Pending Futures (2017), at 15 (referring to L. Gross, 'The Peace of Westphalia, 1648-1948', (1948) 42 American Journal of International Law 29). See also the remarks of J. Pitts, 'Empire and Legal Universalism in the Eighteenth Century', (2012) 117 (1) American Historical Review 92, at 93.

${ }^{5}$ On the particularization of facts requires by eventalization see P. Veyne, Writing History: Essay on Epistemology (1984), at 4-10. See also M. Foucault, 'Question of method', in G. Burchell, C. Gordon and P. Miller (eds.), The Foucault Effect: Studies in Governmentality (1991) 73, at 76.

${ }^{6} \mathrm{P}$. Ricoeur, 'Temps et récit', in L'intrigue et le récit historique (1983), vol. 1, at 290-301.
} 
or $\operatorname{plot}^{7}$ whereby a form is conferred upon an otherwise formless past. ${ }^{8}$ From this perspective, narrativization is more than mere chronolization or any other type of narration in that it produces far more meaning ${ }^{9}$ and resorts to a much wider range of discursive devices. ${ }^{10}$ When narrativization, so understood, is successful, it generates an effet $d u$ réel $l^{11}$ (reality effect ${ }^{12}$ ) in the present, ${ }^{13}$ that is it makes history belong to the category of the discourses of the real as opposed to the discourses of the imaginary. ${ }^{14}$ In international law, the dominant narrativization manifests itself, for instance, in the postulations of causal and linear relations between Grotius and the consolidation of modern international law, between the Alabama arbitration and the peace project of international law, between decolonization and universality, etc., such propositions being always presented as propositions about the real. Third, in this article, the notion of the tale is used as a shortcut for the order of meaning in which the facts that are eventalized and narrativized are registered.

This article is structured as follows. It first briefly outlines the shared eventalization and narrativization of the encounter between China and international law in the English-speaking and Chinese literature (Section 2). This article then sheds light on how, despite sharing a shared eventalization and narrativization, the English-speaking and Chinese-speaking literature diverge as to the order of meaning in which the encounter between China and international law is registered and reflects on the driving forces behind this registration of the encounter between China and international law in two distinct orders of meaning (Section 3). This article ends with some concluding observations (Section 4).

Three final caveats are warranted at this preliminary stage. First, the point in this article is not whether there has actually been such a thing as an 'encounter' between China and international law or whether international law has been imposed 'for real'. After all, as long as an event is made part of a past deemed real by most international lawyers and given a place in the disciplinary history of international law, this event is real for them. ${ }^{15}$ What matters here is how that past is made real and why it is made real the way it is made real. This article is thus not meant to contribute to the historical study of the encounter between China and international law but, more modestly, to provide an inquiry into the contingency (and politics) of the discipline's self-grounding in a past that it deems real.

Second, a clarification is needed as to what this article means when it refers to the 'Englishspeaking' and 'Chinese-speaking' literature. For the sake of this article, the distinction between 'English-speaking' and 'Chinese-speaking' literature is based solely on the language in which the literature concerned is written, irrespective of the origin, mother tongue or affiliation of the author. This specific way of distinguishing between English-speaking and Chinese-speaking bodies of literature, like any construction of difference, ${ }^{16}$ is certainly not unprejudiced. Among

\footnotetext{
${ }^{7} \mathrm{H}$. White, Metahistory. The Historical Imagination in the $19^{\text {th }}$-Century Europe (2014), 7 ('Providing the meaning of a story by identifying the kind of story that has been told is called explanation by emplotment'). See also B. Southgate, 'Postmodernism', in A. Tucker (ed.), A Companion to the Philosophy of History and Historiography (2011), 548.

${ }^{8}$ See, however, the distinction between narrativization and narration, White, supra note 2, at 2.

${ }^{9}$ Ibid., at 42 .

${ }^{10}$ See the remarks of Southgate, supra note 7 , at 541.

${ }^{11} \mathrm{R}$. Barthes, supra note 2, at 74. The 'effet du réél' refers to the feeling that the form, order, and sequence of the past and the way in which the latter is narrated correspond to some kind of necessity.

${ }^{12}$ This is how Alun Munslow translated effet réel of Barthes (xiv), see A. Munslow, 'Preface', in K. Jenkins, On 'What is History'. From Carr and Elton to Rorty and White (1995), xiv.

${ }^{13}$ See Southgate, supra note 7, at 541. See also E. H. H. Carr, What is History? (1987), 25 ('the historian belongs not to the past but to the present').

${ }^{14}$ See White, supra note 2 , at 20.

${ }^{15}$ See, generally, P. Veyne, Did the Greeks Believe in Their Myths?: An Essay on the Constitutive Imagination (1988).

${ }^{16}$ On this question of the construction of difference in legal studies see P. Legrand, 'The same and the different', in P. Legrand and R. Munday (eds.), Comparative Legal Studies: Traditions and Transitions (2003), at 240-411; P. Legrand, 'Foreign Law: Understanding Understanding', (2011) 6 Journal of Comparative Law, at 67-177; J. d'Aspremont, 'Comparativism and Colonizing Thinking in International Law', (2020) 57 Canadian Yearbook of International Law, at 89-112.
} 
others, this particular understanding of the distinction between 'English-speaking' and 'Chinesespeaking' literature entails that, in this article, the former category will include the many works written by Chinese scholars in English. In that respect, a specific observation must be made about Wang Tieya's famous work as it appears in the 1991 Collected Courses and as it originates in his lectures at The Hague Academy of International Law. Wang's work elaborates on the encounter discussed here. The text was originally published in English and later translated to Chinese and published in the 1991 Chinese Yearbook of International Law. This Chinese translation has since been widely cited by later generations of Chinese international lawyers on the topic. In accordance with the abovementioned distinction between 'English-speaking' and 'Chinese-speaking' literature, the two versions of Wang's work are discussed below under the umbrella of 'English-speaking' literature and 'Chinese-speaking' literature respectively. ${ }^{17}$

Third, it must be acknowledged that this article is itself drawn into the historical narratives it discusses, thereby perpetuating and contributing to the eventalization, narrativization, and order(s) of meaning that such narratives perpetuate. In other words, this article is itself not innocent as to the account it provides of the two tales of the encounter between China and international law. ${ }^{18}$ In that sense, the very politics at work in the current histories of international law witnessed in the English-speaking and Chinese-speaking scholarship continue to pervade the very scrutiny thereof which is attempted here.

\section{A shared eventalization and narrativization}

The shared eventalization and narrativization of the sets of facts constitutive of the encounter between China and international law in the English-speaking and Chinese-speaking literature are well-known and ought only to be briefly reminded here. According to such shared eventalization and narrativization, China, following the Opium wars in 1839-1842 and in 1856-1860, was compelled, through the threat to use force and in some instances actual use of force, into a series of international treaties with Western powers constitutive of the so-called treaty port system - sometimes referred to through its oriental equivalent of capitulations. ${ }^{19}$ This treaty port

\footnotetext{
${ }^{17}$ In this article, this abovementioned treatment of the work of Wang Tieya, just like that of other scholars whose work appear in both English and Chinese, takes into account the fact, demonstrated in translation studies, that 'translations have not been perceived as equal to their source texts at all and that, in addition, they are deployed in situations involving highly unequal power relations' (T. Hermans, Translation in Systems. Descriptive and Systemic Approaches Explained (2020), at 54) and that all translations involve a degree of manipulation. See, e.g., T. Hermans (ed.), The Manipulation of Literature. Studies in Literary Translations (1985); A. Berman, 'Translation and the Trials of the Foreign', in L. Venuti (ed.) The Translation Studies Reader (2004), at 276-89; G. Toury, Descriptive Translation Studies and Beyond (1995); T. Hermans, Translation in Systems: Descriptive and System-Oriented Approaches Explained (2014); W. Li, 'A systemic approach to manipulation in translation - a case study of Ye Junjian's 1958 translation of H.C. Andersen's tales', in L. D’hulst, C. O'Sullivan and M. Schreiber (eds.), Politics, Policy and Power in Translation History (2016), at 95-112.

${ }^{18}$ Such posture is sometimes met with the objection that it rests on a performative contradiction. See, e.g., J. Habermas, The Philosophical Discourse of Modernity. Twelve Lectures (translated by F. Lawrence) (1987), at 185-6, 279. See also A. MacIntyre, Three Rival Version of Moral Inquiry. Encyclopaedia, Genealogy, and Tradition (1990), at 55-6. This is also a charge that has surprisingly been raised against Michel Foucault's Archeological work. See H. Dreyfus and P. Rabinow, Michel Foucault: Beyond Structuralism and Hermeneutics (1983), at 88, 99. On the rebuttal of that objection and the idea that being part of what it scrutinizes is the very condition of critique see H. White, Tropics of Discourse (1978), at 142-3, 252-3; P. Ricoeur, La mémoire, l'histoire, l'oubli (2000), at 399; J. Lyotard, La Condition Postmoderne (Editions de Minuit) (1979), at 107; J. Derrida, L'écriture et la différence (Editions du Seuil) (1967), at 46; E. Said, The World, the Text, and the Critic (1983), at 26; M. Foucault, Les mots et les choses (1966), at 12; M. Foucault, Naissance de la biopolitique. Cours au Collège de France (1978-1979) (2004), at 37.

${ }^{19}$ The literature occasionally echoes claims of a dissociation between the treaty port system and international law. From this perspective, the international legal literature contains challenges of the very association commonly made between the design of the treaty port system between China and Western powers and international law. In such accounts, the treaties constitutive of the treaty port system are said to be in contradiction with international law and cannot embody any type of encounter between China and international law. See I. Hsü, China's Entrance into the Family of Nations: The Diplomatic Phase, 1858-1880 (1960), 121-3; A. Anghie, Imperialism, Sovereignty, and the Making of International Law (2004), 73.
} 
system imposed upon China by Western powers provided for juridical and trade privileges, especially in terms of guaranteed entry of goods, freedom of trade and religion, reduction of tariffs, mostfavoured treatment, the renunciation to the subjection of foreigners to Chinese law, and the extraterritorial exercise of jurisdiction through consuls in some determined ports. ${ }^{20}$ From this very dominant perspective permeating both the English-speaking and Chinese-speaking literature, the first international legal regime which bound China amounted to a complex conventional regime imposed upon it by Western powers. ${ }^{21}$ In that common narrative of imposition, international law stands for many things, be it a pre-existing body of rules, an idea, a culture, an idiom, a diplomatic apparatus, etc. Yet, whether the object of this narrative of imposition is a pre-existing body of rules, an idea, a culture, an idiom, a diplomatic apparatus, etc., this narrative is always one that sets up an unequal relationship between two geographically located entities, one subduing the other.

Such eventalization and its narrativization, in terms of the imposition of international law upon China, dominates the twentieth century and twenty-first century English-speaking international legal literature. ${ }^{22}$ It is also heard in French-speaking literature. ${ }^{23}$ The same narrative is espoused by twentieth century Chinese scholars writing on international law in English. ${ }^{24}$ In Chinese literature,

\footnotetext{
${ }^{20}$ See the description of that treaty regimes by A. Becker Lorca, 'Universal International Law: Nineteenth-Century Histories of Imposition and Appropriation', (2010) 51 Harvard Journal of International Law 475, at 511-13. See also A. Peters, 'Unequal Treaties', Max Planck Encyclopedia of International Law (2018), paras. 13-17.

${ }^{21}$ According to GAO Fang, there were, altogether, 745 of such treaties signed. See GAO Fang, “近现代中国不平等条约的 来龙去脉 [Jinxiandai Zhongguo Bupingdeng Tiaoyue de Lailongqumai] (Genesis of Unequal Treaties in modern China)', Social Science of Nanjing, 2018. The most famous are the 1842 Treaty of Nanking between the United Kingdom and Great Qing; the 1843 Treaty on the Trade and Commerce of the Five Ports between Great Qing and the United Kingdom; the 1843 Treaty of the Bogue between the United Kingdom and Great Qing, supplementing the previous Treaty of Nanking; the 1844 Treaty of Wanghia between Great Qing and the United States; the 1844 Treaty of Whampoa between Great Qing and the Kingdom of France; the 1858 Treaty of Aigun between Great Qing and the Russian Empire; the 1858 Treaty of Tientsin between Great Qing, the Russian and Second French Empires, the United Kingdom, and the United States; the 1860 First Convention of Peking between Great Qing and the United Kingdom, the French Empire, and the Russian Empire; the 1864 Treaty of Tarbagatal between Great Qing and the Russian Empire; the 1876 Chefoo Convention between Great Qing and the United Kingdom; the 1885 Treaty of Tientsin between Great Qing and France; the 1890 Convention of Calcutta between the United Kingdom and Great Qing; the 1895 Treaty of Shimonoseki between Great Qing and the Empire of Japan; the 1901 Boxer Protocol between Great Qing and the EightNation Alliance (Austria-Hungary, France, Germany, Italy, Japan, Russia, the United States, and the United Kingdom) and Belgium, Spain and the Netherlands; and the 1915 Twenty-One Demands between the Empire of Japan and the Republic of China. For some authoritative lists of the said unequal treaties see Wang, International Law in China, at 237-62. See A. Peters, supra note 20, para. 10.

${ }^{22}$ W. Grewe, The Epochs of International law (2000), 445-82; M. Koskenniemi, The Gentle Civilizer of Nations (2001), 133; A. Anghie, supra note 19, at 84-5; A. Peters, supra note 20, para. 10; G. Schwarzenberger, A Manual of International Law (1960), 6; O. Yasuaki, International Law in a Transcivilizational World (2017) 80. For an overview of the most common accounts of the expansion of international law to the non-Wester world see W. Jenks, Common Law of Mankind (1958), 71-5. For a reading of the treaty port system as the welcome 'breaking' to the 'stubbornness' of the Chinese government see A. Nussbaum, A Concise History of the Law of Nations (1954), 123 ('China's resistance to contacts with foreign powers took the form of arrogance and humiliating demands; superiority of Chinese civilization, or rather non-existence of any other, was asserted; foreign negotiators were required to perform before the Emperor or his representative a definite number of ceremonious prostrations (kowtows), which, in connection with the expected gifts or tributes, were considered by the Chinese as evidence of Chinese suzerainty. It was only in the nineteenth century that the stubborn attitude of the Chinese was broken').

${ }^{23}$ See, e.g., A. Truyol y Sera, Histoire du droit international public (1995), 107-8; S. Laghmani, Histoire du droit des gens Du Jus Gentium impérial au jus publicum europaeum (2003), 209-13.

${ }^{24} \mathrm{C}$. Cai, The Rise of China and International Law (2019), 16; C. Tang, 'China-Europe', in A. Peters and B. Fassbender (eds.), The Oxford Handbook of the History of International Law (2012), 701-23, at 701; W. Tieya, 'International Law in China: Historical and Contemporary Perspectives', (1991) 221 Collected Courses 195-370, at 237-8, 251; Z. Yang, 'Western International Law and China's Confucianism in the $19^{\text {th }}$ Century: Collision and Integration', (2011) 13 Journal of the History of International Law 285-306, at 298-9; D. Wang, 'The Discourse of Unequal Treaties in Modern China', (2003) 76 Public Affairs 399, at 401. See Hsü, supra note 19, at 138-45; Z. Li, International Law in China: Legal Aspect of the Chinese Perspective of World Order (1995), 67-8 (cited by S. Hamamoto, 'A propos de deux clichés sur l'histoire du droit international en Asie de l'Est: Une reconsidération de l'ordre mondial chinois et du discours de traités inégaux', in P. Dupuy and V. Chetail (eds.), The Roots of International Law: Liber Amicorum Peter Haggenmacher (2014), at 742-56).
} 
this encounter between China and international law is similarly eventalized and narrativized in a way that presents international law as a tool of Western invasion. ${ }^{25}$ If the invasion by warships was straightforward, the 'sugar-coated bullets' of international law was seen as 'more aggressive and having a stronger permeabilising effect'. ${ }^{26}$

It is important to stress that, whilst sharing the same broad eventalization and narrativization of the facts constitutive of the encounter between China and international law, the Englishspeaking and Chinese-speaking literature - unsurprisingly - offered a wide range of variants thereof. Some of the particular traits of the eventalization and narrativization found in the English-speaking and Chinese-speaking literature must be mentioned here.

\subsection{The narrative of imposition in the English-speaking literature}

In the English-speaking literature, the general narrative of imposition is commonly supplemented by specific narratives like those that emphasize the consistency of the treaty port system with the China-centric world view of the Qing dynasty. Indeed, it is sometimes claimed in the Englishspeaking literature that, for the Qing dynasty with whom such treaties were negotiated, foreign nationals were deemed standing at a lower level of civilization than Chinese in China and therefore could not fall within the scope of Chinese law and tributary system. ${ }^{27}$ In the same vein, it is said that the treaty port system and capitulations were a compromise between China's own tributary system and international law and can be read as China's own way to give Western powers a place in the Chinese world. ${ }^{28}$ Likewise, it is sometimes heard that the Qing dynasty never sought any recognition of sovereign equality which would have contradicted its own world view. ${ }^{29}$ In particular, it is reported that starting with the Treaty of Nanjing, the Qing dynasty made it a point that such treaties do not recognize any sovereign equality between China and Western powers. ${ }^{30}$ In that sense, the specific juridical and trade privileges provided by the treaty port system to Western powers are read as accommodating China's understanding of the world and thus as being no privilege of Western powers in the first place. ${ }^{31}$ In the English-speaking literature, such occasional accounts of the treaty port system as reflecting the preferences of the Qing dynasty are sometimes completed by claims that the consular jurisdiction granted to Western powers did not contradict Chinese historical precedents of extraterritoriality that had been granted long before the nineteenth century. ${ }^{32}$ From this perspective, the long tradition of treaties granting extraterritorial jurisdiction had never been controversial because of the Chinese understanding of jurisdiction as being primarily personal rather than territorial. ${ }^{33}$ The same holds for the

\footnotetext{
${ }^{25} \mathrm{HE}$ Zhipeng (何志鹏), ‘Constituent Elements of Chinese Attitudes towards International Law' (中国国际法心态的构成 因素), (2014) 1 Law Review (法学评论), at 87-8; LIU Wenming (刘文明), 'The Civilisation Standard of International Law in $19^{\text {th }}$ Century Europe’ (19世纪末欧洲国际法中的’文明’标准), (2014) 1 World History (世界历史), at 39, 42; LIU Zhiyun (刘 志云), 'On the Evolution of the Relationship between National Interests and International Law' (论国家利益与国际法的关 系演变), (世界经济与政治), (2014) 5 World Economy and Politics (世界经济与政治), at 36-7.

${ }^{26} \mathrm{HE}$ Junyi (何俊毅), ‘The Natural Law Transformation of Wan-Guo-Gong-Fa: on the Spirit of Henry Wheaton's Idea of International Law’ ("万国公法"翻译中的自然法改造——兼论惠顿国际法思想的基本精神), (2016) 1 Chaoyang Law Review (朝阳法律评论), at 119 .

${ }^{27}$ S. Kawashima, 'China', in Peters and Fassbender, supra note 24, at 451-74, at 459. See Hsu, supra note 19, at 139. See Hamamoto, supra note 24, at 750-1. For an overview of the various and sometimes contradictory descriptions of the Chinese tributary systems see Tang, supra note 24, at 701-5.

${ }^{28}$ See Becker Lorca, supra note 20, at 512-13. Arnulf Becker Lorca refers to John Fairbank, 'The Early Treaty System in the Chinese World Order', in J. Fairbank (ed.), The Chinese World Order; Traditional China's Foreign Relations (1968), 257.

${ }^{29}$ The Qing dynasty is said to have refused the stationing of foreign diplomats in Beijing for the same reason. See Kawashima, supra note 27, at 459.

${ }^{30}$ See Kawashima, ibid., at 459.

${ }^{31}$ See Hamamoto, supra note 24 , at 751.

${ }^{32}$ See Becker Lorca, supra note 20, at 520; Tang, supra note 24, at 704; Tieya, supra note 24, at 226-7; Kawashima, supra note 27 , at 459 .

${ }^{33}$ S. Neff, Justice Among Nations (2014), 317. See also Becker Lorca, supra note 20, at 519.
} 
most-favoured nation clause which could be 'regarded as universal benevolence equally provided by the emperor', being something that only the Emperor could provide to others and which others could not provide to the Emperor. ${ }^{34}$ It has also been claimed that the treaties concluded by the Qing dynasty were also concluded with non-European powers which would not have necessarily been in a position to impose anything on China. ${ }^{35}$

Another variant found in the English-speaking literature holds that when negotiating and concluding such treaties, the Qing dynasty did not deem them unequal. ${ }^{36}$ According to such accounts, although the Qing dynasty later recanted its support for such treaties ${ }^{37}$ and made termination a central foreign policy objective, ${ }^{38}$ the Qing dynasty never called such treaties unequal. The term 'unequal treaties' is said to be a twentieth century invention and is commonly traced back to the 1920s Chinese nationalists, ${ }^{39}$ which is supposedly confirmed by the negotiation and implementation of such treaties. ${ }^{40}$

Some other accounts in the English-speaking literature show that the imposition witnessed in the nineteenth century between China and international law has not been that of a body of formal rules but of the vocabulary and discursive categories. ${ }^{41}$ According to such an understanding, the treaty port system should not be construed as a crude form of sovereign colonialism but rather a form of colonizing thinking. ${ }^{42}$

Post-colonial studies have similarly added a new dimension to the narrative of imposition that traditionally populates English-speaking literature. Indeed, such authors have demonstrated the extent to which international law was constituted by its encounter with China as well as other non-Western entities. In particular, drawing on the post-colonial critique of orientalism, ${ }^{43}$ such international legal studies have shown that international law was shaped by the encounter with non-European actors, thereby encoding within the very legal forms of international law the discriminatory features that drove colonialism. ${ }^{44}$ From that perspective, the encounter of international law with China through the treaty port system cannot be limited to a mere exercise of force but should also be read as a foundational event that made international law what it is.

\footnotetext{
${ }^{34}$ See Kawashima, supra note 27 , at 459 . See also Hamamoto, supra note 24, at 751.

${ }^{35}$ For instance, it has also been shown that the extraterritoriality arrangements were not a European monopoly as Peru, Brazil, and Mexico also concluded such agreements. See Neff, supra note 33, at 317; see also Peters, supra note 20 , para. 1.

${ }^{36}$ See D. Wang, China's Unequal Treaties (2005), at 1 . As far as the Treaty of Nanjing is concerned, see Kawashima, supra note 27 , at 459 . See also Hamamoto, supra note 24, at 752.

${ }^{37}$ It has been claimed that it as of the 1870 s that China started to realize some of the problems entailed by such treaties. See Hamamoto, ibid., at 752 . On the idea that these treaties did not comply with the basic principles of international law already at the time see Hsü, supra note 19; Anghie, supra note 19, at 73; Tieya, supra note 24, at 251. For a claim that these treaties would be 'invalid' under twenty-first century international law see Peters, supra note 20, paras. 38-54.

${ }^{38}$ On China's long campaign to revise the unequal treaties and the use of that argument by Chinese nationalists see Tang, supra note 24, at 706-11; Tieya, supra note 24, at 259-62.

${ }^{39}$ See Peters, supra note 20 , para. 4.

${ }^{40} \mathrm{The}$ international legal literature also provides rich accounts of the negotiations of the various treaties of the treaty port system as well as the very painstaking implementation thereof by Chinese authorities, showing the various ways in which foreign powers did not have it their way. For a detailed account of the negotiations and implementations of the Western concessions in Tianjin and their description as being 'ambiguous' see L. Nuzzo, 'The Birth of an Imperial Location: Comparative Perspectives on Western Colonialism in China', (2018) 31 Leiden Journal of International Law 569. See also Becker Lorca, supra note 20, at 519.

${ }^{41}$ See, e.g., T. Ruskola, 'China in the Age of the World Picture', in Hoffman and Orford, supra note 24, at 138-55. See Nuzzo, supra note 40.

${ }^{42} \mathrm{On}$ the notion of colonizing thinking see d'Aspremont, supra note 16 . On the notion of colonizing gesture see J. Butler, Gender Trouble (2007), at 18.

${ }^{43}$ E. Said, Orientalism (1978).

${ }^{44}$ See, generally, Anghie, supra note 19.
} 


\subsection{The narrative of imposition in the Chinese-speaking literature}

The Chinese-speaking literature provides specific variants of the abovementioned shared eventalization and narrativization of the set of facts constitutive of the encounter between China and international law and especially of the narrative of imposition. Three elements of this eventalization and narrativization are worth noting here.

First, the Chinese-speaking literature, especially works that attempt to present an overall review of the history of international law in China, tends to sketch a largely consistent storyline. ${ }^{45}$ This story starts with the Western imposition of international law upon China in the late Qing dynasty, focusing on the treaty port system, the privileges enjoyed by the West and the humiliation on the Chinese part. It then goes on to recount how the Chinese dealt with this situation in various ways, usually culminating in the establishment of the People's Republic of China (the PRC) in 1949, which is seen as marking the true independence of China and the end of the humiliation past.

In this storyline, the 'encounter', or the 'introduction of international law into China', is placed in the context of the Western invasion of China. International law is viewed as a tool in facilitating and legitimizing such invasion, epitomized by the treaty port system. ${ }^{46}$ International law textbooks usually have a section on 'China and international law' in the chapter on the history of international law, which describes the treaties establishing the treaty port system and lists the many privileges Western powers 'plundered' through such treaties. ${ }^{47}$ Thus, this narrative concerning the treaty port system typically stresses the unequal nature of the treaties concerned, the fact that they were imposed upon China by force or the threat of force, and the 'humiliation' on the Chinese part. Wang Tieya, for example, used repeatedly the word 'humiliation' when recounting this history. ${ }^{48}$ Likewise, He Zhipeng and Sun Lu used 'the humiliation of the encounter between modern China and international law' to capture the historical period of the late Qing dynasty. ${ }^{49}$

Another important theme in this storyline is the 'double face' and 'hypocrisy' of international law. Yang Zewei, for example, pointed out that although the West introduced international law to China, they applied international law only among themselves. When it came to their relationship with China, it was instead the unequal treaty port system that applied, which granted the West privileges and facilitated their oppression and exploitation. ${ }^{50}$ This double standard of applying different sets of rules based on a division of the world into 'civilized', 'barbarian', and 'semi-barbarian' nations is noted by many Chinese authors. ${ }^{51}$ Therefore, international law

\footnotetext{
${ }^{45}$ See, e.g, WANG Tieya (王铁崖),'China and International Law: Historical and Contemporary Perspectives' (中国与 国际法一一历史与当代), in Chinese Yearbook of International Law (1991) (中国国际法年刊(1991)) (1992); YANG Zewei (杨泽伟), Macro-history of International Law (宏观国际法史) (2001), at 414-31; HE Zhipeng (何志鹏) and SUN Lu (孙璐), 'The Notion of International Law of China: An Analysis Based on the History of International Relations' (中 国的国际法观念：基于国际关系史的分析)，(2015） 5 Journal of International Relations and International Law (国际关 系与国际法学刊).

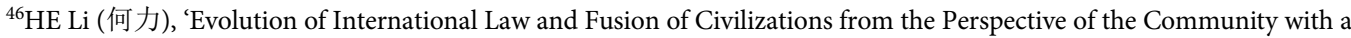
Shared Future for Mankind' (人类命运共同体视角下的国际法史与文明互融), (2019) 6 Journal of Xiamen University (Arts \& Social Sciences)（（), General Serial No. 256, at 46; YANG Yunpeng (杨云鹏) and MENG Yuqun (孟于群), 'Theories and Practices of China's Abrogation of Unequal Treaties' (中国废除不平等条约的理论与实践), (2013) 26(4) Journal of Yunnan University Law Edition (云南大学学报法学版), at 125-6.

${ }^{47}$ See, e.g., ZENG Lingliang (曾令良) ed., Public International Law (国际公法学) (2018). This textbook belongs to the 'key textbooks' of a 'Marxism Theory Research and Construction Project', which is promoted by the government in various ways, sometimes making it quasi-mandatory to use them as the main textbook. While other materials are generally used to supplement these textbooks, they are now widely designated as the principal textbooks in Chinese law schools.

${ }^{48}$ See WANG (王铁崖), supra note 45.

${ }^{49}$ See HE (何志鹏) and SUN (孙璐), supra note 45 , at 50 .

${ }^{50}$ See YANG (杨泽伟), supra note 45 , at 431.

${ }^{51}$ See LIU (刘文明), supra note 25, at 39-40; LIN Xuezhong (林学忠), From Public Law of All Nations to Public Law Diplomacy: The Introduction, Interpretation and Application of International Law in Late Qing (从万国公法到公法外交 一晚清国际法的传入诠释与应用) (2009), at 218-19.
} 
is viewed as a hypocritical pretext for Western aggression, a 'cloak' that covers the bullying of the weak by the powerful colonizers. ${ }^{52}$

He Zhipeng argues that this historical experience and understanding of international law as 'hypocritical' have a direct impact on the contemporary Chinese attitude towards international law. He listed various incidents throughout the first half of the twentieth century, including the Treaty of Portsmouth between Russia and Japan in 1905, China's experience at the Paris Peace Conference in 1919, and the reaction of the League of Nations after the Japanese occupation of the northeast of China in 1931, to demonstrate how international law had 'betrayed' the Chinese, and thus made it difficult for the Chinese to trust international law even today. ${ }^{53}$ Zhang Yongle also referred to the disillusion of Chinese elites at the Paris Peace Conference and asserted that it had an even more profound impact: awakened by such disillusion, the Chinese revolutionists gave up the 'old path' of following the footstep of the West and seeking their recognition; instead, they denied the Western hierarchy of civilization, and sought to establish a new world order. ${ }^{54}$

A second notable feature of the narrative of imposition in the Chinese-speaking literature is that the encounter of China and international law is seen first and foremost as an 'encounter of civilizations'. For example, as a historian, Lin Xuezhong studies the 'introduction of international law' not as part of a disciplinary history of international law, but as an analytical framework to examine the modern Chinese state-building process. Thus, Lin sees international law as a new value system and conceptual paradigm, the introduction of which ultimately changed the way in which the Chinese understood and constructed the world order. ${ }^{55}$

Indeed, it is a common feature, especially among the works of historians, to view the introduction of international law as a process of introducing new concepts, ideologies and ways of thinking that challenged the traditional Chinese world order and ultimately led to the reconstruction of a new 'world image' in the Chinese mind ${ }^{56}$ In this process, the concept of 'civilization' is considered the 'main thread'. ${ }^{57}$ For many, the so-called 'civilization' is only Western 'civilization', and international law is seen as a 'carrier' of Western culture and values, and thus the imposition of international law upon China signifies the imposition of Western civilization. ${ }^{58}$ It is also argued that even today, this mentality of the West to impose its own civilization upon the non-Western world is still present, albeit taking more subtle forms. ${ }^{59}$

Legal historian Lai Junnan, on the other hand, considered that what was most important was not the never-defined standard of 'civilization', but the discourse of 'civilization', which divided the world into 'civilized' and 'uncivilized', and applied to them different legal regimes. ${ }^{60}$ Thus, Liu Wenming considers 'civilization' as a concept that Western states used to serve their colonizing projects, based on which they constructed a hierarchical world order. ${ }^{61}$ But interestingly, as Lai pointed out, this also means that 'civilization' became the hope of the colonized states: if they manage to become a 'civilized' country, they would become equal to the colonizers. ${ }^{62}$

\footnotetext{
${ }^{52}$ See HE (何志鹏) and SUN (孙璐), supra note 45, at 53; ZOU Lei (邹否), “Research on “Pre-Qin International Law” and the Reconstruction of A Chinese “World Picture”: From William AP Martin to Chen Guyuan’, (“先秦国际法”研究与中国”世 界图景”的重建一从一丁韪良到陈顾远), (2009) 3 International Review (国际观察) 25.

${ }^{53}$ See HE (何志鹏), ibid., at 88 .

${ }^{54}$ ZHANG Yongle (章永乐), 'From Said to China: A Reading of “Legal Orientalism”' (从萨义德到中国——“法律东方主 义"的一种读法), (2016) 4 China Law Review (中国法律评论) 176.

${ }^{55}$ LIN (林学忠), supra note 51, at 2-4.

${ }^{56}$ See, e.g., ZOU (邹否), supra note 52, at 28.

${ }^{57}$ LAI Junnan (赖骏楠), International Law and Late Qing China: Texts, Events and Politics (国际法与晚清中国：文本、 事件与政治), (2015) Shanghai People's Press (上海人民出版社), at 5.

${ }^{58}$ TIAN Tao (田涛), The Import of International Law and Late Qing China (国际法输入与晚清中国) (2001), at 12-13; HE (何力), supra note 46, at 44-5; LIU (刘文明) supra note 25, at 33-5.

${ }^{59}$ See ZHANG (章永乐), supra note 54 , at 174; LIU (刘文明), ibid., at 42 .

${ }^{60}$ See LAI (赖骏楠, supra note 57 , at 9-10.

${ }^{61}$ See LIU (刘文明), supra note 25 , at 42.

${ }^{62}$ See LAI (赖骏楠), supra note 57 , at 9 .
} 
This paradox leads to the third point we want to highlight in the Chinese-speaking literature on the 'encounter', i.e., there is a certain ambivalence towards the introduction of international law. On the one hand, Western invasion and the dubious role of international law in serving Western colonial projects are criticized. On the other hand, it is acknowledged that China's acceptance of international law and entry into the international system is a positive, progressive development. One typical example is the story of W. A. P. Martin's translation of Wheaton's Elements of International Law (titled 'Wanguo Gonfa' in Chinese, meaning 'public law of all nations') to which the attention must turn briefly.

The translation of Wanguo Gongfa is a central marker in the eventalization and narrativization of the encounter between China and international law in the Chinese-speaking literature. ${ }^{63}$ It is generally considered the beginning of the 'formal and systematic' introduction of international law in China. ${ }^{64}$ It is thus often acknowledged that Martin's work had, 'objectively', some positive effects, including brought to China knowledge about the international system, helped Qing officials in their diplomatic activities, and promoted the 'modernisation of China's diplomacy'. ${ }^{65}$ On the other hand, historians and lawyers alike conducted extensive research upon the motivation of Martin in translating this text. The mainstream holds a critical view which believes that the purpose of his translation was to justify Western intervention, to urge the Chinese to accept Western norms, and to force China into the Western world order. ${ }^{66}$ Mention is also commonly made to Martin's religious purpose of teaching the Qing government 'God and his eternal truth', and bring to the Chinese 'some Christian spirit'. ${ }^{67}$ This sort of evaluation of something having certain 'objectively' positive effects but carrying a malicious purpose is frequently seen in the Chinese-speaking literature concerning the encounter of China and international law. ${ }^{68}$

\footnotetext{
${ }^{63}$ In comparison, it is noteworthy that in the English-speaking legal literature, the translation of Wheaton's Elements of International Law is only occasionally mentioned. See the recent article by M. Carrai, "The Politics of History in the Late Qing Era: William A.P. Martin and a History of International Law for China', (2020) 22 Journal of the History of International Law, at 269-305. See also Kawashima, supra note 27, at 462-4; Neff, supra note 33, at 313; Tang, supra note 24, at 705. The English-speaking legal literature contrasts with English-speaking translation studies where the translation of Wheaton's Elements of International Law has been extensively studied. See, e.g., L. Liu, 'Legislating the Universal: The Circulation of International Law in the Nineteenth Century', in L. Liu (ed.), Tokens of Exchange. The Problem of Translation in Global Circulations (1999), 127-64; R. Svarverud, International Law as World Order in late Imperial China: Translation, Reception and Discourse. 1847-1911 (2007), 69-132; E. Cheung and M. Fung, 'The Hazards of Translating Wheaton's Elements of International Law into Chinese: Cultures of World Order Lost in Translation', in A. Carty and J. Nijman (eds.), Morality and Responsibility of Rulers: European and Chinese Origins of a Rule of Law as Justice for World Order (2018).

${ }^{64}$ See LIN (林学忠), supra note 51, at 48; see also YANG (杨泽伟), supra note 45, at 416.

${ }^{65}$ ZHANG Yanqing (张燕清), 'On William Martin and Wango Gongfa: The Beginning of Eastward Spreading of International Law’ (丁韪良与"万国公法"一一兼论国际法学东渐之肇始), (2003) 29(3) Journal of Xuzhou Normal Univeristy (Philosophy and Social Sciences Edition) (徐州师范大学学报 (哲学社会科学版)67, at 70; ZHANG Jingcao (张劲草) and QIU Zaijue (邱在珏), 'On the Introduction of International Law into China' (论国际法之传入中国), (1984) 2 Journal of Hebei University (河北大学学报) 131.

${ }^{66}$ TIAN Tao (田涛), 'William Martin and “Wanguo Gongfa” (丁韪良与"万国公法"), (1999) 5 Social Science Research (社会 科学研究), at 99-103; YANG (杨泽伟), supra note 45, at 418; LIN (林学忠), supra note 51, at 14; ZOU (邹否), supra note 52, at 23 .

${ }^{67}$ See LIN (林学忠), ibid., at 66; FU Deyuan (傅德元), 'New Revelations on the Original Edition of Wanguo Gongfa and the Purposes of its Translator, W.A.P Martin’ (丁韪良"万国公法"翻译蓝.本及意图新探), (2008) 1 Historical Research in Anhui (安徽史学), at 53 .

${ }^{68}$ It is interesting to note that when they pick these facts and make it an 'event', international lawyers writing in Englishspeaking language, do narrativize it in a way that showcase the advantages of international law for China. Indeed, the few international lawyers who have paid attention to the matter relish to report that, the same year as the distribution of Martin's translation of Wheaton, following an incident between Prussia and Denmark in Chinese territorial waters, the Zongli Yamen invokes the strategically edited Chinese translation of Wheaton's Elements of International Law to successfully argue for the illegality of the Prussian action. As the story goes in the English-speaking literature, as a reward for his collaboration in the production of a Chinese version of Henry Wheaton's Elements of International Law, William A. P. Martin is made professor of international law at the Tongwen Guan Library, that is the Academy of Foreign Languages, and later the first chancellor of the Imperial University of Peking. The narrativization of Martin's translation of Wheaton's Elements of International Law that is
} 
In fact, such ambivalence already existed in the process of the 'encounter', which has been the subject of much scholarly attention. Lin Xuezhong examined how late Qing Chinese officials and intellectuals understood international law both as an instrument for Western invasion and as a potential tool for the independence and development of China. ${ }^{69}$ Lai Junnan analysed how the Chinese in the late Qing dynasty had misunderstood international law, and thus had difficulty and pain in reconciling the natural law promise of justice and the reality of inequality and exploitation by the West. ${ }^{70}$ Philosopher Wang Zhongjiang studied the contradictory views on international law among late Qing Chinese and explained such contradiction by referring to their different roots in Chinese traditional thinking, and different reactions to the colonial situation of China at that time. ${ }^{71}$ It is interesting to see that such contradictions and ambivalence are still present today. According to He Zhipeng and Sun Lu, this ambivalence is indeed the general attitude of China towards international law even today, and it has everything to do with China's experiences and memories of the history of the 'encounter'. ${ }^{72}$

\section{Two tales of an encounter}

Whilst the English-speaking and Chinese-speaking literature provide, notwithstanding the many variants and specific twists which have been outlined in the previous section, a shared eventalization and narrativization of the set of facts constitutive of the encounter between China and international law, it is argued in this section that what is made of such encounter in each of these bodies of literature is very different. This section elucidates the very distinct tales of the encounter between China and international law - and thus the orders of meaning in which the facts constitutive thereof are registered - that are found in the English-speaking and Chinese-speaking scholarship respectively. In shedding light on the diverging tales at work in the English-speaking and Chinese-speaking scholarship, this section will show that these divergences are not innocent.

\subsection{The English-speaking literature: A modern tale}

It is argued here that, as far as the English-speaking literature is concerned, the eventalization and narrativization of the set of facts constitutive of the encounter of China and international law in terms of imposition fit well with the modern modes of thinking about international law. In that sense, such an eventalization and narrativization can be seen as the manifestation of a very Western modernism. It suffices here to mention a few of the modern traits of the eventalization and narrativization of the set of facts constitutive of the encounter of China and international law in terms of imposition. For instance, it can be said that the narrative of imposition provides a spatial origin to the universality of international law, one that is spatially and temporarily

found in the few English-speaking works that refer to it thus projects an image of international law as being a tool can be used by all parties to their advantage. Indeed, it offers a story of the translation and distribution of international legal texts in China as a means for the Qing dynasty to gain the upper hand over the West by using the tools of the West. See Kawashima, supra note 27, at 451-74; see also Neff, supra note 33, at 313; Tang, supra note 24, at 705.

${ }^{69}$ See LIN (林学忠), supra note 51, at 28, 68 .

${ }^{70}$ See, generally, LAI Junnan (赖骏楠), 'The Misread New World: Impression of International Law of the Chinese in Late Qing Dynasty’ (误读下的新世界：晚清国人的国际法印象), (2011) 1 Tsinghua Discourses on Rule-of-Law (清华法 治论衡).

${ }^{71}$ See, generally, WANG Zhongjiang (王中江), 'The Morality and the Shade of Power of International Law in World Order: The Legitimisation of Wanggo Gongfa in Late Qing China and Its Limitations' (世界秩序中国际法的道德性与权 力身影—一而国公法'在晚清中国的正当化及其限制), in WANG Zhongjiang (王中江) and LI Cunshan (李存山) (eds.), Chinese Confucianism (中国儒学) (2017), vol. XII.

${ }^{72}$ See, generally, HE (何志鹏) and SUN (孙璐), supra note 45; see also HE (何志鹏), supra note 25. Similar arguments can also be seen in English-speaking literature. See, e.g., S. Chesterman, 'International Criminal Law with Asian Characteristics?', (2014) 27(2) Columbia Journal of Asian Law 129. 
identifiable and traceable. ${ }^{73}$ The origin provided by the dominant eventalization and narrativization is one that is internal to international law as it is the latter that has been supposedly extended spatially and temporarily, thus owing its universality only to itself. Such a type of internal and selfreferential origin is a common mark of modern legal thought.

The eventalization and narrativization of the set of facts constitutive of the encounter of China and international law in terms of imposition also has the effect of locating international law in time and space. Indeed, according to this eventalization and narrativization, China is just a piece of that space to which international law can apply to. Thus, by virtue of such eventalization and narrativization, international law is presented as created somewhere and then extended to somewhere else in space, leaving no space potentially unabsorbable in the space of international law. This eventalization and narrativization thus perpetuate the general modern geographical mapping of the world. At the same time, the eventalization and narrativization of the set of facts constitutive of the encounter of China and international law nourishes a very linear temporality. In fact, by virtue of this encounter, there is a precise and identifiable 'before' and 'after' the encounter of China and international law. The rift in time and space between an international law made in Europe and a Chinese empire alien to international $\mathrm{law}^{74}$ is bridged, all of it being absorbed in a commensurable time and space. In the same vein, the eventalization and narrativization of the set of facts constitutive of the encounter of China and international law in terms of imposition presupposes a universal translatability of international legal texts, of the latter categories and concepts. ${ }^{75}$ It is as if international law is semantically, conceptually and culturally translatable into Chinese terms and categories of thoughts and addresses any types of relations between China and other entities. ${ }^{76}$ Such a type of commensurability and totalizing thinking is a common trait of European modern thinking. ${ }^{77}$

The narrative of imposition presupposes that there was such a thing as a stable set of international legal rules and international legal principles applied by a certain set of actors which was simply and mechanically extended as to apply to a new actor which had so far remained alien to it. In particular, this narrative of imposition is premised on some preconceived materiality of international law, the movability of the latter in what is supposed to be a common shared space, and a certain idea of material encounter with a subject or territory which had not yet experienced such materiality. ${ }^{78}$ This whole idea of encounter, albeit forced or under the threat of the use of force, is built on a presupposed shared materiality as well as shared space and the possibility of the former being experienced in the latter.

The eventalization and narrativization of the set of facts constitutive of the encounter of China and international law in terms of imposition can also be read as a mode of silencing an 'other'. Indeed, according to such eventalization and narrativization, China is an 'other' which international law speaks on behalf of. ${ }^{79}$ China is never defined but through what international law says it is. And this is how, as is commonly acknowledged today, ${ }^{80}$ what allows the eventalization and

\footnotetext{
${ }^{73}$ See, generally, M. de Certeau, L'écriture de l'histoire (1975).

${ }^{74} \mathrm{~J}$. Derrida, The Beast and the Sovereign (2011), vol. II, at 9 ('between my world and any other world there is first the space and the time of an infinite difference, an interruption that is incommensurable with all attempts to make a passage, a bridge, an isthmus, all attempts at communication, translation, trope, and transfer that the desire for a world or the want of a world, the being wanting a world will try to pose, impose, propose, stabilize').

${ }^{75}$ See MacIntyre, supra note 18 , at 171.

${ }^{76} \mathrm{~B}$. Latour, La fabrique du droit. Une ethnographie du Conseil d'Etat (2004), at 235.

${ }^{77}$ See MacIntyre, supra note 18 , at 172 .

${ }^{78} \mathrm{On}$ the use of the state to build the space in international law see S. Pahuja, 'Laws of encounter: a jurisdictional account of international law', (2013) 1 London Review of International Law 63, at 63-98.

${ }^{79}$ J. Derrida, The Beast and the Sovereign (2011), vol. I, at 5; see also de Certeau, supra note 73, at 15.

${ }^{80}$ See, generally, L. Obregon, 'The Civilized and the Uncivilized', in B. Fassbender and A. Peters (eds.), The History of International Law (2012), 917; L. Obregon, 'Completing civilization: Creole consciousness and international law in nineteenth-century Latin America', in A. Orford (ed.), International Law and its Others (2006), 247-63; V. S. A. Kumar, 'A Propletic Approach to Postcolonial Legal Studies? A Brief Look at the Relationship Between Legal Theory and
} 
narrativization of the set of facts constitutive of the encounter of China and international law in terms of imposition perpetuate an image of a world dominated by the West and shaped around a Western-centric geography while producing a history according to very modern and European terms. ${ }^{81}$ In this respect, there seems to be no doubt that this narrative of imposition reinforces the centrality of Europe and perpetuates the making of the history of international law a part of the history of Western civilization. In the same vein, such eventalization and narrativization bear strong empowering dimensions, obviously for the Western imposers which are held to be 'powers', but also for the Chinese recipient of international law which are, in this narrative, represented as mighty, but just not as mighty enough to resist the mightier Western powers.

The eventalization and narrativization of the set of facts constitutive of the encounter of China and international law in terms of imposition can thus be read as a very modern construction whose resilience in the English-speaking literature should thus not be surprising. As has been discussed here, such eventalization and narrativization register the encounter of China and international law in a very modern order of meaning, one that organizes origin, space, time, rules, and ultimately the other.

\subsection{The Chinese-speaking literature: A tale of nation-building}

It is submitted here that the very same eventalization and narrativization of the set of facts constitutive of the encounter of China and international law in terms of imposition come to serve a very different take in the Chinese-speaking literature. In the Chinese-speaking literature, such eventalization and narrativization situate the 'encounter' within the tale of the modern Chinese nation-building process.

In Wang Zhongjiang's article about late Qing Chinese attitudes towards international law, Wang ends his analysis with a very interesting question: 'In their [late Qing Chinese] mind, why would not China, a country that had maintained the central position in the world for a very long time, possess the power of a strong nation once again?'82 Wang's purpose is to analyse the attitudes of late Qing Chinese towards international law, but he ends by posing a question concerning the destiny of China. In fact, this is common in the Chinese-speaking literature on the 'encounter'. They might be concerned with the general history of international law in China, or with very specific issues like the translation of a single concept. But no matter what the specific focus is, there seems to be a common understanding of viewing the introduction of international law first and foremost as a critical event in the modern Chinese nation-building process. As legal scholar He Qinhua put it, the most important feature of the development of modern Chinese international law as a discipline, is that it went hand in hand with 'the process of "the Chinese people have stood up"" 83

'The Chinese people have stood up' is a famous slogan often attributed to Mao Zedong at the ceremony of the establishment of the PRC in 1949, although it was actually said on other occasions. ${ }^{84}$ In any case, in the Chinese collective memory, it has become a powerful and symbolic

Intellectual History', (2003) 2 Law, Social Justice and Global Development, available at warwick.ac.uk/fac/soc/law/elj/lgd/2003_ 2/kumar/; S. Pahuja, 'The Postcoloniality of International Law', (2005) 46 Harvard International Law Journal 459. On the idea that the standard of civilization continues its ordering function today see G. W. Gong, 'Standard of Civilization Today', in M. Mozaffari (ed.), Globalization and Civilizations (2002), 77-96; G. W. Gong, 'Empires and Civilizations: The Search for Standards Continues', (2010) 12 International Studies Review 144.

${ }^{81}$ See, generally, d'Aspremont, supra note 3, at 89-115.

${ }^{82}$ See WANG (王中江), supra note 71 , at 214 .

${ }^{83} \mathrm{HE}$ Qinhua (何勤华), 'The Birth and Development of Modern International Law in China' (中国近代国际法学的诞生 与成长), (2004) 4 The Jurist (法学家), at 60.

${ }^{84}$ QU Chunjiao (曲春郊), ‘When Did Mao Zedong Declare “Chinese People Had Stood Up”' (毛泽东何时宣告’中国人民 从此站起来了'? ), (1995) 6 Literature of Chinese Communist Party (法学家), at 46; “The Famous Mao Slogan, That He Never Even Used', South China Morning Post, 25 September 2009, available at www.scmp.com/article/693526/famous-mao-sloganhe-never-even-used (accessed 17 January 2021). 
declaration of the independence of China, ending the 'one hundred years of humiliation' at the hands of Western and Japanese invasion since the First Opium War of 1840. Indeed, the establishment of the PRC is the climax in the official and mainstream tale of modern Chinese nationbuilding, which, before Mao's proud announcement of victory, is full of pain, suffering, struggle, and, above all, 'humiliation'.

The discourse of national humiliation already took shape at the beginning of the twentieth century, and is one of the few discourses that are endorsed by both the Nationalists and the Chinese Communist Party (the CCP) ${ }^{85}$ It was replaced by a 'victory narrative' in the Mao era, which emphasized class struggle rather than foreign invasion as the cause of Chinese sufferings, and emphasized victory rather than humiliation. ${ }^{86}$ After the end of the Cultural Revolution (1966-1976), as the communist ideology lost credibility, and especially after the Tiananmen protest, the CCP resorted to patriotism as its principle basis of legitimacy. Modern Chinese history became an important part of this ideological campaign as the CCP was portrayed as the saviour of China from the 'humiliation' inflicted by foreign invaders. ${ }^{87}$ The 'humiliation narrative' has since become the master narrative in China on modern Chinese history. Through history education, museums, commemorations, and popular culture, it permeates into every aspect of the daily life of the Chinese, and becomes deep-rooted in the Chinese psyche.

The eventalization and narrativization of the set of facts constitutive of the encounter of China and international law operate within the confines of the master 'humiliation narrative' and forms part of it. The literature examined above all share this historical narrative as their common background, even though the research questions and objectives of the authors vary. Among the authors we examined, some particularly stress the 'humiliation' and pain suffered by the Chinese and the injustice and hypocrisy of international law and of Western powers, ${ }^{88}$ while others, and particularly later generations of scholars, have less interest in the 'humiliation' per se. Lin Xuezhong, for example, deliberately chose to avoid an 'aggression-resistance' or 'anti-imperialism' analytical framework. ${ }^{89}$ Likewise, Lai Junnan states that compared to criticizing what the 'imperialist' countries did, it is more important to reflect upon the 'more fundamental structural elements' underlying their behaviours. ${ }^{90}$ Nevertheless, this does not mean that they do not endorse the 'humiliation narrative'. On the contrary, it is precisely because the humiliation and suffering of China during this period of time had become an established fact that they felt no need to dwell on it anymore. ${ }^{91}$

On the other hand, 'humiliation' is not just about victimization, but also about resistance and victory. In this sense, the narrative of imposition is not only about China's forced acceptance of international law, but also about how the Chinese struggled to find a way to react to such imposition. As Lin Xuezhong put it, the introduction of international law is in fact 'a process of continuous local interpretation, application and appropriation'. ${ }^{92}$ Other authors also

\footnotetext{
${ }^{85}$ W. Callahan, 'National Insecurities: Humiliation, Salvation, and Chinese Nationalism', (2004) 29(2) Alternatives: Global, Local, Political, at 209-11.

${ }^{86}$ W. Callahan, 'History, Identity and Security: Producing and Consuming Nationalism in China', (2006) 38(2) Critical Asian Studies, at 185; Z. Wang, 'National Humiliation, History Education, and the Politics of Historical Memory: Patriotic Education Campaign in China', (2008) 52(4) International Studies Quarterly, at 789.

${ }^{87}$ Ibid., at 788-94.

${ }^{88}$ See WANG (王铁崖), supra note 45; see also YANG (杨泽伟), supra note 45; HE (何志鹏) and SUN (孙璐), supra note 45 .

${ }^{89}$ See LIN (林学忠), supra note 51 , at 30.

${ }^{90}$ See LAI (赖骏楠), supra note 57 , at $177-8$.

${ }^{91}$ When explaining that he would not adopt the 'anti-imperialist' framework, Lin Xuezhong stated at the same time that such an analytical framework 'would of course be helpful to understand the suffering of China in modern history', see LIN (林学忠), supra note 51, at 30 .

${ }^{92}$ Ibid., at 390 .
} 
emphasized the active attempt to interpret and apply international law by the Chinese to their own benefits at the time of the 'encounter'. ${ }^{93}$

Furthermore, the eventalization and narrativization of the set of facts constitutive of the encounter of China and international law are as much about the past as it is about today and the future. Thus, we find He Zhipeng and Sun Lu sketching a storyline from 'the humiliation of the encounter between modern China and international law' to 'China's return to the international system and gradual rise'; ${ }^{94}$ we find Lai Junnan asking how to build an international society with shared values but at the same time respecting the differences of nations, and what contributions different nation-states should make in building such an international society. ${ }^{95}$ Zhang Yongle's review of China's historical interaction with international law likewise leads to a future direction: China will not be merely a 'follower' of the Western rules of the game, but should aim at providing the 'Chinese solution' to the world's common problems, and having a bigger impact on 'other nations and civilisations'. ${ }^{96}$

In this sense, if the eventalization and narrativization of the set of facts constitutive of the encounter of China and international law posit the 'encounter' as part of the tale of modern Chinese nation-building, the story does not end there. It is 'to be continued' and connected with the later story of the further development and 'rise' of the nation. The literature examined here thus also forms part of a larger body of literature on the relationship between China and international law, which is showing growing interest in the future role of China in shaping international law. ${ }^{97}$

While the reading of this growing body of literature is beyond the scope of this article, it is worth noting the connection, as well as the fact that this later body of literature seems to reflect precisely the reality of China's rise and the scholarly reflections upon China's new role in the world. Scholars, as individuals, certainly have their own objectives, believes and sentiments, but they are also inevitably influenced by the consciousness of their time, and such influence is often reflected in scholarly works. Such works would become part of a textual discourse, or discourses, which, in turn, would contribute to shaping the consciousness of the time. Our discussion here is concerned with these textual discourses and the consciousness they reflect, not the personal objectives or believes of the authors. And it is in these textual discourses we observed the entanglement of the story of the 'encounter' with the story of modern Chinese nation-building, a story that contemporary authors are continuing to write and nourish.

\section{Concluding remarks: Inverse symmetries and the possibility of a disciplinary history}

The foregoing has shed light on the shared eventalization and narrativization of the facts constitutive of the encounter between China and international law witnessed in English-speaking and Chinese-speaking literature. It has shown that albeit espousing a shared narrative of imposition

\footnotetext{
${ }^{93}$ See TIAN (田涛), supra note 58, at 168-354; ZHANG Yongxin (张用心), 'Some Facts about Wanguogonfa' ("万国公 法”的几个问题), (2005) 42(3) Journal of Peking University (Philosophy and Social Sciences) (北京大学学报（哲学社会科学 版)).

${ }^{94}$ See HE (何志鹏) and SUN (孙璐), supra note 45, at 43 .

${ }^{95}$ See LAI (赖骏楠), supra note 57 , at 179.

${ }^{96}$ See ZHANG (章永乐), supra note 54 , at 177.

${ }^{97}$ See, e.g., HE Li (何力), 'Evolution of International Law and Fusion of Civilizations from the Perspective of the Community with a Shared Future for Mankind' (人类命运共同体视角下的国际法史与文明互融), (2019) 6 Journal of Xiamen University (Arts \& Social Sciences) (厦门大学学报 (哲学社会科学版)); XU Chongli (徐崇利), 'Hard \& Soft Competencies and China's Impact upon International Law' (软硬实力与中国对国际法的影响), (2012) 34(1) Modern Law Science (现代法学); ZHANG Xiaojun (张晓君) and WEI Binbin (魏涁涁), 'International Law and Major Country Diplomacy with Chinese Characteristics’ (国际法与中国特色大国外交), (2019) 1 China International Studies (国际问题研究).
} 
(Section 2), the English-speaking and Chinese-speaking literature have registered the facts constitutive of the encounter between China and international law in a very distinct order of meaning, thereby producing very different tales about it (Section 3).

It is submitted at this ultimate stage that, in the previous sections' account of the encounter of China and international law found in the English-speaking and Chinese-speaking literature, there are more than two distinct tales. There are tales that are inversely symmetrical. Indeed, when taken individually, each of these tales speaks about and on behalf of another that is absent. As was highlighted above, when individually speaking about the absent other, each of them constitutes the speaking subject. Yet, the symmetry goes further than that: the speaking subject of each of these two tales constitutes the absent other in the other tale. In fact, the absent China in the English-speaking modern tale on behalf of which it is spoken and which comes to constitutes the West is the very subject of the national tale which dominates the Chinese-speaking literature. Conversely, the absent West in the Chinese-speaking national tale on behalf of which it is spoken and which comes to constitute the national China is the very subject of the modern tale which dominates English-speaking literature. Said differently, the absent other in each of these tales is the constituted subject of the other tale.

Mentioning the reverse symmetry of the two tales of the encounter between China and international law is not meant to be in any way spectacular, let alone surprising. ${ }^{98}$ What such reverse symmetry shows, however, is that disciplinary histories, just like that of international law, are plural and coexist side-by-side without contradicting one another, and always leaving the impression that the discipline is built on a unique and universal history made of the same events and narrativized the same way. That claim can even be pushed further. It is the possibility of coexisting but inversely symmetrical tales about the history of the discipline that allows the discipline to have a disciplinary history in the first place and that enables that disciplinary history to be experienced as a universal necessity by all the members of that discipline.

\footnotetext{
${ }^{98}$ On the reduction of the past to muted and de-contextualized monuments see M. Foucault, L'archéologie du savoir (1969), at 15 . See also de Certeau, supra note 73 , at 74 .

Cite this article: d'Aspremont J and Zhang B (2021). China and international law: Two tales of an encounter. Leiden Journal of International Law 34, 899-914. https://doi.org/10.1017/S0922156521000431
} 